O. O. Oliinyk, Cand. Sc. (Econ.), Assoc. Prof., orcid.org/0000-0002-3941-2286
National University of Water and Environmental Engineering, Rivne, Ukraine, e-mail: oliynuk_olena@ukr.net

\title{
SOCIAL RESPONSIBILITY ASSESSMENT IN THE FIELD OF EMPLOYMENT (CASE STUDY OF MANUFACTURING)
}

Purpose. To develop methodological framework for the assessment of social responsibility in the field of remuneration and its informational support in manufacturing by types of economic activity.

Methodology. This paper draws on theoretical and methodological concerns of modern economics, research works by domestic and foreign scientists with regard to issues of social and employment sphere, social responsibility, and decent work. While investigating the issue, the authors used the following research methods: generalisation, systematisation, analysis and synthesis (to analyse theoretical and methodological advances regarding the assessment of social responsibility in employment relations); statistical analysis (to diagnose informational support of implementing social responsibility); aggregation (to assess social responsibility in the field of remuneration); comparative analysis (to diagnose the level of social responsibility in the field of remuneration in manufacturing by types of economic activity); expert assessments (to substantiate the weighting coefficients of partial indices).

Findings. The research generalised and systematised approaches of scientists in terms of determining the content of social responsibility in employment relations, as well as analysed existing methodological framework for the assessment of social responsibility and criteria of international standards in this field. Basing on the received data, the paper substantiated the indicators for the assessment of social responsibility in the field of remuneration with their distribution to incentives and disincentives. The authors developed an aggregate index to determine the level of social responsibility in the field of remuneration and tested its calculation with regard to manufacturing in Ukraine by types of economic activity.

Originality. The methodological framework of social responsibility assessment in the field of remuneration, which is based on the calculation of the aggregate index that uses incentives and disincentives, has been improved. Unlike the current practice, the methodological principles use the indicators that characterise the level of compliance with the requirements of legislation, as well as additional obligations, in terms of social responsibility concept.

Practical value. The developed and substantiated methodological principles allow assessing the effectiveness of remuneration regulation in various types of economic activity, as well as the level of material well-being of employees with sufficient objectivity. The use of the social responsibility index in the field of remuneration allows determining "bottlenecks" in social policy basing on obtained partial and aggregate indicators and defining priority directions of social and employment sphere development. It will also serve as a basis for improving the interaction of social partners and substantiating their requirements and suggestions when concluding collective employment agreements at different levels.

Keywords: social responsibility, remuneration, employment relations, wages, salaries, salary arrears, benefit allowances

Introduction. Over the last decade, one can see that new patterns of world economic thought are emerging. There is a clear orientation towards the achievement of social priorities. At the same time, there is a vibrant recognition that new kinds of concepts are needed: more inclusive, less destructive of society and the planet. Hence, one can see that scholars investigate such categories as "socioeconomics", "socially oriented economy", "social responsibility", "decent work", and others. Particular attention is currently being paid to the issues of socially responsible regulation of social and employment relations, which cover all the basic functions of HR management.

Hence, the main trend in the development of foreign companies is to formulate a competitive social policy, which shows the desire of management not only to maximise profits, but also to recognise pronounced importance of the social security of employees, to create decent working conditions, to preserve and enrich human capital and, ultimately, to enhance corporate social responsibility [1].

There is surely a need for the social responsibility development in the field of compensations and benefits as social standards of remuneration directly set important parameters of relations between employees, employers and the state. This concerns their interests and therefore leads to a certain reaction that can be desirable (implementation and adherence to social standards) or undesirable (sabotaging the observance of social standards in covert forms or direct resistance and lobbying for their disqualification). According to the current vision of the institutional economics, there are two cases when people will, in fact, adhere to social standards or at least will not wrestle against them ideologically, politically and economically. First case is, when social standards are the point of equilibrium or consensus between the positions of the major stake-

(C) Oliinyk O. O., 2020 holders. Second case is, when the system uses coercive mechanisms without involving any private interest [2].

It is worth pointing out that in Ukraine the corporate social responsibility concept is understood at the theoretical level, but is not yet sufficiently implemented in business practice. The existing remuneration issues in all areas of economic activity, including industry, which is one of the most important spheres required to ensure dynamic growth on a new technological basis, clearly demonstrate this trend. Nowadays, researchers pay a lot of attention to the analysis of remuneration at the macro level, in the regions, and at companies. At the same time, in some business areas scholars paid less attention to this issue, for instance, in industry. However, in Ukraine industry has always been a significant area of employment, generating demand for highly skilled labour [3]. Therefore, the study of the state of remuneration by type of economic activity in industry and the assessment of the level of implementing corporate social responsibility in this field is a vital scientific task.

Literature review. Unsolved aspects of the problem. Many Ukrainian and foreign authors, including O.Amosha [4], D. Bayur, N. Bocharova [5], O. Grishnova [6], M. Delini [7], A. Carroll, E. Libanova [2], D. Nahaivska [8], H. Nazarova, O. Novikova, O. Pankova [9], M. Saprykina [10], V. Smachylo [11], R. Freeman and others have investigated the essence of social responsibility and development of methodological approaches to assessing its level. Social responsibility, in its most general interpretation, contains external and internal components that meet the expectations of external (consumers, competitors, local community, contractors, public authorities, etc.) and internal (employees) stakeholders. Consequently, the available approaches to its assessment are based on indicators that are grouped by stakeholder categories, among which the first group is "company employees" [7]. At the same time, the 
existing papers suggest the assessment both of the average salary and various social expenses that contribute to the development of company staff.

A certain peculiarity of modern social responsibility assessment techniques is that they include quantitative and qualitative indicators where remuneration is one of the other areas of social responsibility implementation. Thus, D. Nahaivska [8] believes that indicators in this area belong to the direction "Ensuring decent and safe working conditions", whereas V.Smachylo [11] analyses them together with others in the challenging field of "Labour practices".

Scientists also suggest grouping the indicators of internal social responsibility according to its types, namely: organisational and economic, legal, technical and technological, ecological, social and cultural, ethical, and philanthropic social responsibility, determining their level on a scale (low score -0 points; satisfactory -1 point; below average -2 points; average -3 points; above average -4 points; high -5 points) [5].

The researchers at the Institute of Industrial Economics of the NAS of Ukraine [4] have developed an integral indicator of industrial labour potential development based on the social responsibility, which is calculated as a multidimensional normalised average, whereas its additive model provides for the determination of the impact of each index on the relative change of the indicator. At the same time, remuneration is only one of ten areas of study within labour potential development.

Antoniuk V. investigates remuneration trends in industry, in particular from the point of view of "decent pay" category. The author analyses the level of wages and their dynamics, the distribution of the number of employees by the amount of payroll, the arrears of pay. The scholar also compares the increase in nominal wages compared to the rate of increase in consumer prices, the ratio of the average monthly wage to the actual subsistence according to types of economic activity in industry [3].

Pankova O. assesses the state of social and employment relations in industry on the basis of social responsibility, concluding that it is the presence of arrears of pay, late payment of current wages, increasing arrears, slow settle of arrears of pay at the companies that destabilise social and employment relations at industrial enterprises of Ukraine [9].

After analysing scientific achievements in this area, one can underline that remuneration is one of the most important areas of implementing social responsibility to employees. The importance of these socially responsible practices is primarily linked to the fact that the motivation level largely determines the employees' quality of life. Therefore, decent pay should be considered a priority area of social responsibility and a key factor in the long-term competitiveness of the employer in the labour market, especially while facing significant risks of labour migration from Ukraine.

The existing scientific and methodological foundations provide the basis for assessing social responsibility. However, the issues of informational support of such assessment in the field of remuneration remain insufficiently studied. The same situation is with the appropriateness of taking into account factors that have both a positive impact and a negative one on the level of socially responsible regulation of remuneration, as well as the use of indicators that characterise statutory obligations and voluntary obligations of employers in excess of legal standards.

Purpose. To develop methodological bases of social responsibility assessment in the field of remuneration, to substantiate their information support and test them by types of economic activity in industry of Ukraine.

Results. Current trends in the development of corporate social responsibility (CSR) in Ukraine suggest that, for the vast majority of companies, pay is a priority in the implementation of their social policy. Thus, according to the CSR Development in Ukraine [10], socially responsible practices for their own employees are the most common CSR implementation path: $76 \%$ of companies implement policies to develop and improve working conditions for staff (Figure). At the same time, $59 \%$ of respondents said that they do not carry out special measures in the field of employment relations.

At the same time, companies that implement socially responsible measures have the most widespread practices that directly relate to remuneration: pay raises, bonus payments, and "white" wages. The given peculiarity of social responsibility demonstrates the low level of remuneration in Ukraine; therefore, both employers and employees pay much attention to this issue.

Thus, remuneration is one of the most important aspects of social responsibility, so indicators for its evaluation are an integral part of international standards in this area. For instance, the international standard SA 8000 (Social Accountability 8000) [12], which measures social performance and helps to develop an effective management system aimed at improving the working conditions and standard of living of employees, in section 8 "Remuneration" contains the following evaluation criteria:

- the company shall ensure that wages paid for a standard working week shall always meet at least legal or industry minimum standards and shall be sufficient to meet basic needs of personnel and to provide some discretionary income;

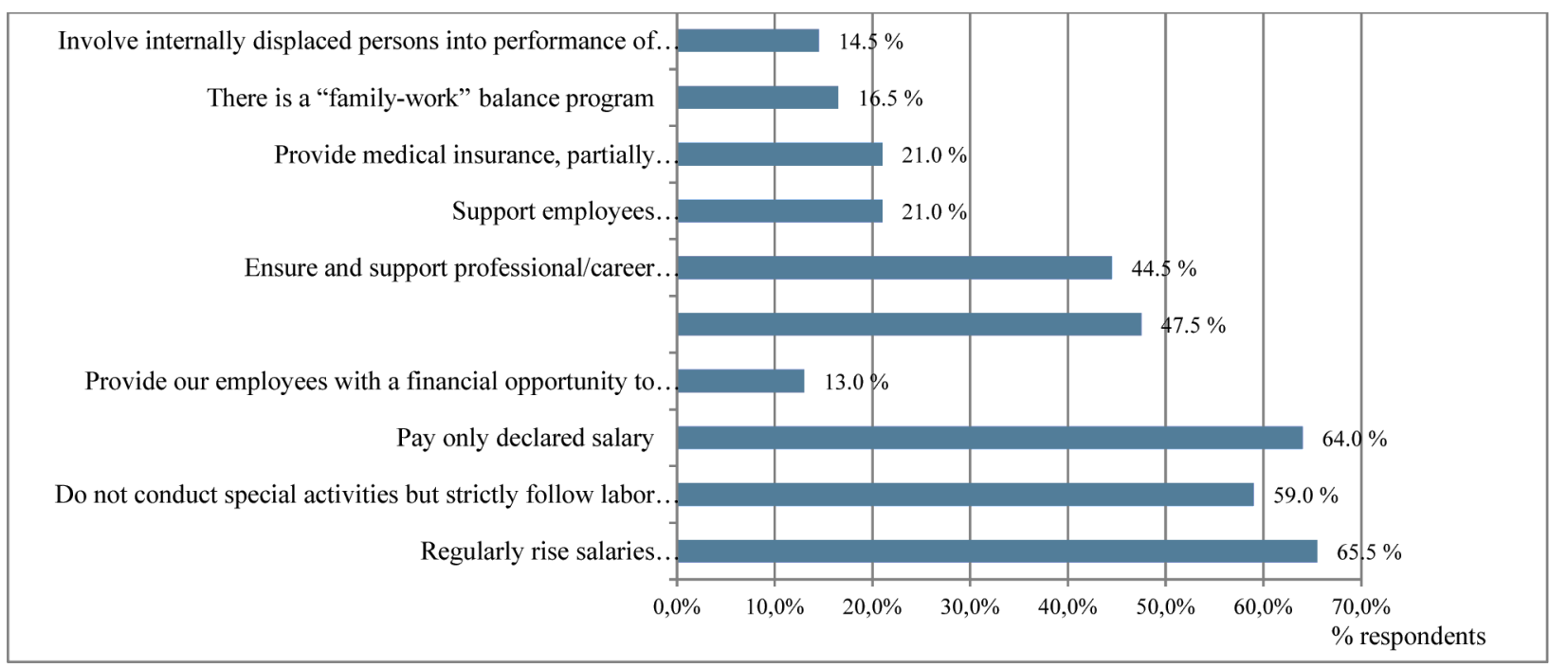

Fig. Labour Practices at Ukrainian Companies [10] 
- the company shall ensure that deductions from wages are not made for disciplinary purposes, and shall ensure that wage and benefits composition are detailed clearly and regularly for workers; the company shall also ensure that wages and benefits are rendered in full compliance with all applicable laws and that remuneration is rendered either in cash or cheque form, in a manner convenient to workers;

- the company shall ensure that labour-only contracting arrangements and false apprenticeship schemes are not undertaken in an effort to avoid fulfilling its obligations to personnel under applicable laws pertaining to labour and social security legislation and regulations.

The GRI (Global Reporting Initiative) standards, in particular the G4 Sustainability Reporting Guidelines [13], view remuneration indicators in different aspects. In the Equal Remuneration for Women and Men aspect, there is a G4-LA13 indicator, which characterises gender equality in remuneration and is defined as the ratio of basic salary and remuneration of women to men by employee category, by significant locations of operation. In the Employment Aspect, there is a G4-LA2 indicator, which characterises benefits provided to full-time employees that are not provided to temporary or part-time employees, by significant locations of operation. These include, as a minimum: life insurance, health care, disability and invalidity coverage, parental leave, retirement provision, stock ownership, and others.

Hence, the issue of remuneration assessment basing on social responsibility is quite complicated. It is worth mentioning that nowadays there are sufficiently elaborated and well-known methods for assessing corporate social responsibility $[5,7,11]$. There are important scientific achievements in the assessment of internal social responsibility by its various components [1, $6,9]$. However, the scholars have not suggested any appropriate methods within the framework of social responsibility research in the field of remuneration yet. At the same time, their development is imperative given that in the process of regulating remuneration it is necessary to justify management measures and decisions that will allow ensuring decent remuneration level. Consequently, assessing social responsibility in the field of remuneration is an essential prerequisite for improving the overall regulatory process and creating the basis for socially responsible interaction of social partners.

Therefore, taking into account the positive practices of scientists who study social responsibility and its evaluation and the peculiarities of social responsibility in the field of remuneration, there exist developed methodological foundations that allow a comprehensive assessment of social responsibility in the sphere of remuneration.

The system of social responsibility assessment in the field of remuneration should take into account all the most important indicators that reflect the level of compliance with the legislation and regulations. At the same time, the concept of social responsibility implies accepting additional, voluntary obligations that go beyond legal and regulatory standards.

Basing on the results of previous studies and the availability of up-to-date statistics of the State Statistics Service of Ukraine, the author suggested using the integrated method. In this regard, the author proposed determining the level of social responsibility in the field of remuneration on the basis of an aggregate index, which is based on the straightforward criteria that characterise the most important aspects of decent compensation for the working efforts of employees. The use of aggregate estimates allows ranking the types of economic activity in industry, as well as regulating remuneration within the social partnership system.

Partial indices, included in the general corporate social responsibility index in the field of remuneration $\left(\mathrm{CSRI}_{\mathrm{re}}\right)$, characterise the level of observance of employment rights of employees, guaranteed by legal acts, both at the legislative level and at the level of agreements within the framework of social partnership, and additional obligations provided by employers in the context of implementing their social responsibility. The equation for calculating $C S R I_{r e}$ is provided below

$$
\operatorname{CSRI}_{r e}=\alpha \cdot I_{1}+\beta \cdot I_{2}+\xi \cdot I_{3}+\delta \cdot I_{4}+\varepsilon \cdot I_{5}+\phi \cdot I_{6},
$$

where $C S R I_{r e}$ is the corporate social responsibility index in the sphere of remuneration; $I_{1}, I_{2}, \ldots, I_{6}$ are partial corporate social responsibility indices in the sphere of remuneration; $\alpha, \beta, \ldots, \phi$ are weight coefficients.

Since the purpose of the study is to determine the level of corporate social responsibility in the field of remuneration by types of economic activity in industry, the author believes that the approach in which the maximum value of a specific component of the assessment is taken as a reference [14] shall be the most appropriate one, i.e.

$$
I_{i}=\frac{Q_{f_{i}}-Q_{\min _{i}}}{Q_{\max _{i}}-Q_{\min _{i}}},
$$

where $Q_{f_{i}}$ are the actual values of the individual components of the partial indices; $Q_{\min _{i}}$ are the minimum values of individual components of partial indices; $Q_{\max _{i}}$ are the maximum values of individual components of partial indexes.

The assessment uses both factors that positively influence the level of corporate social responsibility (stimulants) and those that exert a negative influence (destimulants). For the latter, (2) will be transformed as follows

$$
I_{3}=\frac{Q_{\max _{i}}-Q_{f_{i}}}{Q_{\max _{i}}-Q_{\min _{i}}} .
$$

The author has selected six indicators for the assessment of corporate social responsibility in the field of remuneration, namely: wage growth rate; the ratio of wages of women to men; the share of workers (in \%) whose wage payments are within the legislative minimum (destimulant); the ratio of wages to the industry average; the ratio of the amount of arrears of pay to the payroll (destimulant); the share of financial assistance (in \%) in the payroll.

One should bear in mind that the proposed indicators are not equitable by their importance. The ambiguity of their effect on the total index can be smoothed out by introducing weights into the (1). The author has substantiated the selected weight coefficients for the indicators of corporate social responsibility assessment in the field of remuneration basing on the results of the expert survey. Hence, the coefficients are as follows: wage growth rate -0.21 ; the ratio of wages of women to men -0.08 ; the share of workers whose wage payments are within the legislative minimum -0.11 ; the ratio of wages to the industry average -0.21 ; the ratio of the amount of arrears of pay to the payroll -0.22 ; the share of financial assistance in the payroll -0.17

There is a need to emphasize that quantitative indicators systematised in the statistical abstracts for the respective years $[15,16,17]$ are the information support of the proposed parameters. Thus, with the use of the statistical data, it is possible to calculate the actual values of the individual constituents of the partial indices and determine their minimum and maximum values.

In order to test the methodological principles, the author calculated corporate social responsibility indices in the field of remuneration by types of economic activity in the industry in 2016-2018 (Table).

After the analysis of the corporate social responsibility index in the field of remuneration of various types of economic activity in industry, one can underline that none of them reached the maximum value. The highest index value was in 2018 at the companies involved in manufacture of pharmaceuticals and medicinal chemical products $(0.833)$; the lowest value was recorded in manufacture of chemicals and chemical products $(0.23)$. 
ङ

\begin{tabular}{|c|c|c|c|c|c|c|c|c|c|c|c|c|c|c|c|c|c|c|}
\hline \multirow[b]{3}{*}{ 2 } & $\mid \begin{array}{l}8 \\
0 \\
0\end{array}$ & 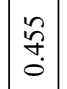 & \begin{tabular}{|c|}
$\vec{\infty}$ \\
$\stackrel{\sigma}{0}$
\end{tabular} & 萨 & 辛 & 导 & 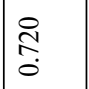 & ત્ণి & $\begin{array}{l}\infty \\
\infty \\
\infty \\
0 \\
0\end{array}$ & 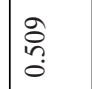 & 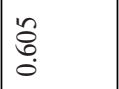 & 脢 & \begin{tabular}{|l|}
$\mid$ \\
0 \\
0 \\
0 \\
0
\end{tabular} & $\begin{array}{c}\mathscr{O} \\
\stackrel{1}{0} \\
0\end{array}$ & $\frac{m}{n}$ & $\begin{array}{l}\infty \\
\stackrel{\infty}{\infty} \\
\stackrel{\infty}{0}\end{array}$ & 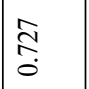 & 粱 \\
\hline & $\begin{array}{c}\tilde{n} \\
\tilde{n} \\
0\end{array}$ & 咅 & \begin{tabular}{c}
$f$ \\
\multirow{f}{0}{} \\
\end{tabular} & 号. & 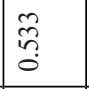 & 䍄 & 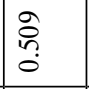 & సి & $\begin{array}{l}\stackrel{0}{\infty} \\
\infty \\
0\end{array}$ & $\begin{array}{l}0 \\
\text { o } \\
0 \\
0\end{array}$ & $\stackrel{f}{f}$ & 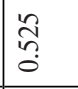 & $\begin{array}{c}\tilde{n} \\
\hat{n} \\
0\end{array}$ & 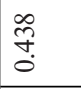 & 竎 & 宇 & 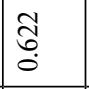 & ๙ิ \\
\hline & 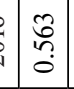 & $\begin{array}{c}\widetilde{\approx} \\
\tilde{\sigma} \\
\end{array}$ & $\begin{array}{l}0 \\
0 \\
\vdots \\
0 \\
0\end{array}$ & 害 & 㹲 & 命 & 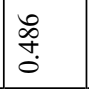 & $\begin{array}{l}\vec{\infty} \\
\stackrel{\infty}{o} \\
\end{array}$ & $\begin{array}{l}\mathscr{2} \\
\approx \\
0 \\
0\end{array}$ & $\begin{array}{l}0 \\
\hat{n} \\
0 \\
o\end{array}$ & $\begin{array}{l}\text { 索 } \\
\text { वे }\end{array}$ & 今. & $\begin{array}{l}0 \\
\cdots \\
0 \\
0\end{array}$ & $\begin{array}{l}\infty \\
\hat{n} \\
\hat{0}\end{array}$ & 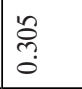 & 守 & 苞 & $\begin{array}{l}\overrightarrow{0} \\
0 \\
0\end{array}$ \\
\hline \multirow[b]{3}{*}{ 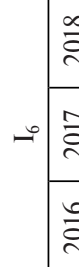 } & $\begin{array}{ll}0 \\
0 \\
0 \\
0\end{array}$ & \begin{tabular}{|c|} 
\\
\hdashline \\
\hdashline
\end{tabular} & స్సે & त्ञ & $\bar{\partial}$ & $\underset{\hat{y}}{\stackrel{m}{0}}$ & $\frac{\infty}{\infty}$ & 拿 & 会 & 号 & 年 & 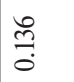 & $\stackrel{\infty}{\stackrel{\infty}{\circ}}$ & ठ্ & $\frac{\infty}{\infty}$ & స్ & $\underset{-}{\stackrel{9}{9}}$ & 嗐 \\
\hline & $\begin{array}{c}0 \\
\tilde{n} \\
0\end{array}$ & 吕 & 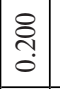 & $\frac{8}{0}$ & $\begin{array}{l}\stackrel{\circ}{0} \\
\stackrel{0}{0}\end{array}$ & 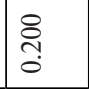 & 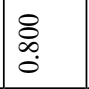 & 导 & $\underset{.}{8}$ & $\begin{array}{l}\mathscr{0} \\
\stackrel{0}{0} \\
0\end{array}$ & $\begin{array}{l}\stackrel{0}{0} \\
\stackrel{0}{0}\end{array}$ & ำ & $\frac{8}{0}$ & $\begin{array}{l}\stackrel{0}{0} \\
\stackrel{0}{0} \\
0\end{array}$ & 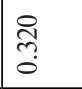 & 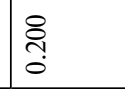 & $\underset{-}{\stackrel{8}{.}}$ & : \\
\hline & \begin{tabular}{l}
$n$ \\
\hdashline \\
0 \\
0
\end{tabular} & ¿े & $\begin{array}{c}\infty \\
\stackrel{0}{0} \\
0\end{array}$ & ণั & 文 & 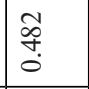 & 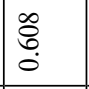 & $\stackrel{8}{8}$ & 导 & 年 & $\stackrel{\widetilde{7}}{0}$ & พิ & 离 & : & 宗 & $\overrightarrow{\tilde{\sigma}}$ & 究 & $\underset{-}{8}$ \\
\hline \multirow{3}{*}{$\approx$} & $\begin{array}{l}\infty \\
0 \\
0 \\
0 \\
0\end{array}$ & $\begin{array}{l}: \\
h \\
n \\
o \\
0\end{array}$ & $\mid \begin{array}{l}0 \\
0 \\
0\end{array}$ & $\begin{array}{l}\text { ț } \\
\text { So }\end{array}$ & $\begin{array}{l}\infty \\
\stackrel{\circ}{\circ} \\
\stackrel{0}{0}\end{array}$ & 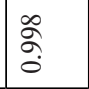 & $\begin{array}{l}\infty \\
\stackrel{0}{\circ} \\
\stackrel{0}{0}\end{array}$ & ¿̊. & $\underset{8}{8}$ & 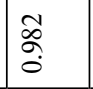 & $\begin{array}{l}0 \\
\text { a } \\
0\end{array}$ & $\begin{array}{l}n \\
\infty \\
\infty \\
0 \\
0\end{array}$ & 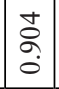 & $\frac{1}{0}$ & के & 早 & $\begin{array}{c}\widetilde{0} \\
\infty \\
0 \\
0\end{array}$ & 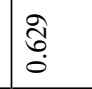 \\
\hline & $\mid \begin{array}{c}\hat{n} \\
\hat{n} \\
o\end{array}$ & ồ̊ & 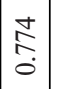 & ga & 会 & $\mid \begin{array}{l}\infty \\
\infty \\
\infty \\
0\end{array}$ & $\mid \begin{array}{l}\tilde{D} \\
\infty \\
\\
o\end{array}$ & 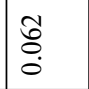 & $\underset{-}{\stackrel{8}{8}}$ & $\vec{\sigma}$ & $\begin{array}{l}\infty \\
\infty \\
\infty \\
\infty\end{array}$ & 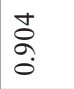 & \begin{tabular}{|l|}
0 \\
0 \\
0 \\
0 \\
0
\end{tabular} & $\stackrel{\hat{Q}}{0}$ & 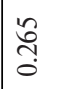 & $\begin{array}{l}\stackrel{2}{2} \\
\stackrel{0}{0}\end{array}$ & ஓ & : \\
\hline & \begin{tabular}{l}
$\overrightarrow{0}$ \\
\hdashline \\
0
\end{tabular} & 嵩 & 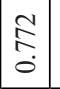 & 守 & ô. & 尺े & $\begin{array}{l}\infty \\
0 \\
0 \\
0\end{array}$ & $\begin{array}{l}\infty \\
\infty \\
\infty \\
\infty \\
\infty\end{array}$ & बूे & $\begin{array}{l}\text { کू } \\
\text { o. }\end{array}$ & హ̆ & $\begin{array}{l}8 \\
\vdots \\
0 \\
0\end{array}$ & $\begin{array}{c}2 \\
0 \\
\infty \\
0 \\
0\end{array}$ & 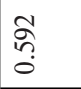 & 范 & है & $\bar{\sigma}$ & $\begin{array}{l}n \\
\infty \\
\infty \\
0 \\
0\end{array}$ \\
\hline \multirow{3}{*}{$\mp$} & \begin{tabular}{l|l}
0 \\
$\vdots$ \\
$\vdots$ \\
0
\end{tabular} & 总 & $\begin{array}{l}\hat{\imath} \\
\text { ปे } \\
0\end{array}$ & $\stackrel{n}{\stackrel{c}{0}}$ & $\stackrel{\infty}{0}$ & $\frac{0}{0}$ & 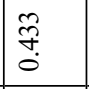 & స్ & $\underset{-}{8}$ & 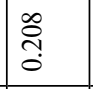 & 文 & 景 & 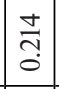 & $\frac{m}{0}$ & స్ & 吕 & $\stackrel{0}{7}$ & $\begin{array}{l}0 \\
\\
0 \\
\end{array}$ \\
\hline & $\begin{array}{l}\overrightarrow{\widehat{N}} \\
\tilde{\sigma}\end{array}$ & 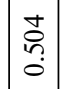 & 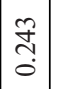 & $\frac{\infty}{0}$ & 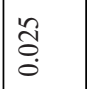 & 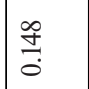 & 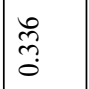 & 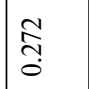 & 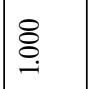 & $\frac{\Omega}{\sigma}$ & है & 导 & $\frac{\Re}{0}$ & $\frac{\partial}{\partial}$ & ત્ર & $\begin{array}{l}\stackrel{\circ}{N} \\
\stackrel{0}{0}\end{array}$ & 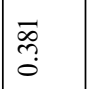 & ¿̊. \\
\hline & $\begin{array}{l} \pm \\
\vdots \\
0 \\
0\end{array}$ & 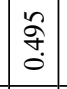 & 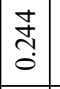 & $\frac{5}{0}$ & @ి & $\frac{0}{0}$ & 点 & ๙ે & $\underset{-}{8}$ & $\frac{a}{0}$ & 亲 & $\frac{n}{7}$ & $\frac{\mathfrak{g}}{0}$ & $\frac{\infty}{0}$ & ণิ & ڤે & 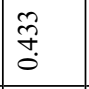 & 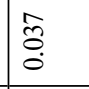 \\
\hline \multirow{3}{*}{$=$} & $\begin{array}{c}\stackrel{R}{0} \\
\infty \\
0 \\
0\end{array}$ & 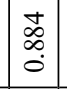 & $\begin{array}{l}2 \\
\sigma \\
\sigma\end{array}$ & ๙ิ & @̊. & 苦 & $\begin{array}{l}\stackrel{\partial}{\partial} \\
\stackrel{0}{\circ}\end{array}$ & $\begin{array}{l}\infty \\
\stackrel{\infty}{f} \\
0\end{array}$ & $\underset{-}{8}$ & $\begin{array}{l}n \\
\tilde{\sigma} \\
0\end{array}$ & $\begin{array}{l}0 \\
\vdots \\
0 \\
0\end{array}$ & 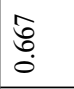 & \begin{tabular}{|c|}
$\hat{2}$ \\
o. \\
0
\end{tabular} & $\begin{array}{l}n \\
0 \\
0 \\
0\end{array}$ & $\begin{array}{l}\tilde{0} \\
\tilde{0} \\
0\end{array}$ & $\begin{array}{l}\infty \\
\stackrel{\infty}{f} \\
0\end{array}$ & $\stackrel{8}{\circledR}$ & $\begin{array}{l}0 \\
n \\
0 \\
0\end{array}$ \\
\hline & 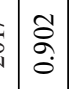 & $\begin{array}{l}\vec{\sigma} \\
\text { o }\end{array}$ & 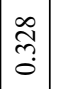 & @̊ & 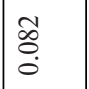 & $\stackrel{Ð}{\circ}$ & 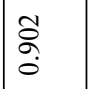 & $\begin{array}{l}\stackrel{0}{0} \\
b \\
0\end{array}$ & $\bar{\sigma}$ & 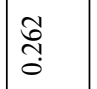 & $\stackrel{n}{\stackrel{2}{2}}$ & ठુ. & $\vec{m}$ & $\vec{m}$ & $\begin{array}{l}\overrightarrow{0} \\
\text { ?. } \\
0\end{array}$ & $\bar{m}$ & $\underset{-}{\stackrel{一}{~}}$ & 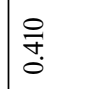 \\
\hline & $\begin{array}{l}f \\
⿱ \\
\infty \\
0 \\
0\end{array}$ & \begin{tabular}{|l|}
$\infty$ \\
$\check{\delta}$ \\
$\delta$
\end{tabular} & $\frac{m}{\vec{\sigma}}$ & $\begin{array}{l}\text { ర్ } \\
\\
\end{array}$ & $\begin{array}{l}\text { ర్ } \\
. \\
\end{array}$ & $\begin{array}{l}8 \\
\\
\end{array}$ & $\underset{.}{\stackrel{0}{0}}$ & 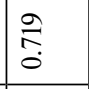 & $\begin{array}{l}\circ \\
\vdots \\
\vdots\end{array}$ & $\begin{array}{l}\infty \\
\stackrel{\infty}{0} \\
\end{array}$ & $\begin{array}{l}\text { त्रे } \\
0 \\
0\end{array}$ & iे & \begin{tabular}{|l|}
$\infty$ \\
$\stackrel{\infty}{0}$ \\
0 \\
\end{tabular} & $\stackrel{m}{\tilde{\sigma}}$ & 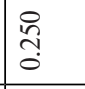 & 3 & ò & \begin{tabular}{l}
2 \\
\multirow{0}{0}{} \\
0
\end{tabular} \\
\hline \multirow{3}{*}{ 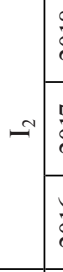 } & 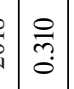 & ¿े & $\begin{array}{c}\hat{f} \\
\stackrel{0}{0}\end{array}$ & م્ & $\stackrel{\circ}{\circ}$ & $\mid \begin{array}{l}\hat{\partial} \\
\partial \\
0\end{array}$ & \begin{tabular}{l}
0 \\
\multirow{0}{0}{} \\
0 \\
0
\end{tabular} & $\stackrel{n}{\stackrel{n}{0}}$ & 吕 & 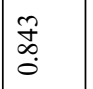 & 足 & $\begin{array}{l}0 \\
\mathscr{0} \\
0 \\
0\end{array}$ & \begin{tabular}{|c|} 
\\
\multirow{2}{*}{} \\
0 \\
0 \\
0
\end{tabular} & î. & 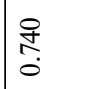 & 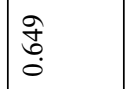 & 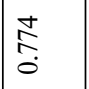 & ふू. \\
\hline & $\begin{array}{l}\stackrel{R}{0} \\
\tilde{0} \\
0\end{array}$ & 吕 & $\underset{\substack{R \\
0}}{0}$ & $\begin{array}{l}0 \\
\infty \\
\infty \\
0 \\
0\end{array}$ & 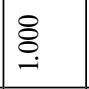 & $\hat{a}$ & ㄱ. & $\hat{o}$ & $\begin{array}{l}\mathscr{2} \\
\approx \\
0 \\
0\end{array}$ & $\begin{array}{l}\vec{F} \\
\stackrel{5}{0} \\
0\end{array}$ & fô & 苦 & $\begin{array}{l} \pm \\
\vdots \\
O\end{array}$ & 官 & $\begin{array}{l}+ \\
\stackrel{0}{0} \\
\stackrel{0}{0}\end{array}$ & $\begin{array}{l}5 \\
0 \\
0 \\
0\end{array}$ & $\begin{array}{l} \pm \\
\infty \\
\infty \\
0\end{array}$ & 会 \\
\hline & $\begin{array}{l}\infty \\
\tilde{0} \\
\tilde{0}\end{array}$ & \& & $\mid \begin{array}{l}0 \\
0 \\
0 \\
0\end{array}$ & ڤ్రి & $\stackrel{8}{.}$ & $\stackrel{1}{\stackrel{2}{0}}$ & 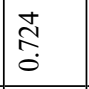 & $\stackrel{n}{\stackrel{n}{0}}$ & $\widehat{\widehat{\sigma}}$ & $\stackrel{8}{0}$ & $\begin{array}{l}\overrightarrow{0} \\
\hat{o} \\
0\end{array}$ & $\frac{\infty}{n}$ & $\stackrel{n}{\stackrel{n}{0}}$ & $\hat{\tilde{b}}$ & $\overrightarrow{\widehat{d}}$ & 命 & $\stackrel{m}{\stackrel{2}{0}}$ & $\begin{array}{l}0 \\
\infty \\
0 \\
0\end{array}$ \\
\hline \multirow{3}{*}{ 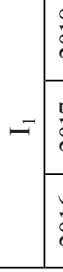 } & $\begin{array}{l}0 \\
0 \\
0 \\
0\end{array}$ & $\begin{array}{l}\vec{n} \\
\text { in } \\
0\end{array}$ & $\mid \begin{array}{l}\mid \\
0 \\
0 \\
0 \\
0\end{array}$ & $\begin{array}{l}0 \\
\text { d. } \\
\text { o. }\end{array}$ & 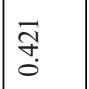 & $\begin{array}{l}\text { 离 } \\
\text { on }\end{array}$ & $\underset{-}{\stackrel{8}{\circ}}$ & 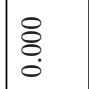 & 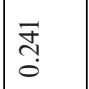 & 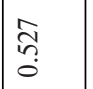 & $\begin{array}{l}n \\
0 \\
0 \\
0\end{array}$ & ôे & $\mid$\begin{tabular}{l}
\multirow{2}{0}{} \\
$\hat{o}$
\end{tabular} & స్ & 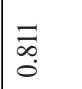 & 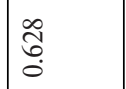 & 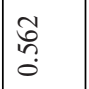 & $\begin{array}{l}n \\
2 \\
i n \\
o\end{array}$ \\
\hline & 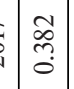 & 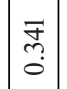 & 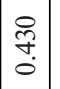 & 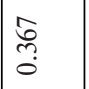 & 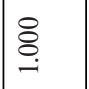 & $\mid \begin{array}{l}n \\
\infty \\
n \\
o\end{array}$ & 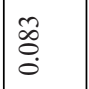 & $\stackrel{\text { సे }}{\sigma}$ & $\stackrel{+}{\stackrel{5}{0}}$ & 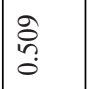 & $\stackrel{\widehat{a}}{0}$ & 辇 & 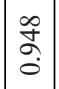 & స్ర్ర & $\begin{array}{l}m \\
\stackrel{m}{\alpha} \\
0\end{array}$ & 突 & $\stackrel{8}{8}$ & $\begin{array}{l}\hat{\infty} \\
\tilde{\sigma}\end{array}$ \\
\hline & 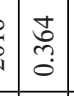 & \begin{tabular}{|l|} 
\\
导 \\
\end{tabular} & 尃 & $\begin{array}{l}\text { 尔 } \\
\\
\end{array}$ & $\begin{array}{l}0 \\
\text { S. } \\
0\end{array}$ & $\begin{array}{l}1 \\
\tilde{n} \\
0 \\
0\end{array}$ & 音 & 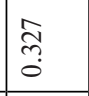 & $\begin{array}{l}\mathscr{0} \\
\stackrel{0}{0} \\
0\end{array}$ & 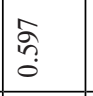 & 文 & $\stackrel{8}{\circ}$ & \begin{tabular}{|l|}
$\overrightarrow{5}$ \\
a \\
\end{tabular} & 杄 & \begin{tabular}{|l|} 
\\
$\infty$ \\
0 \\
0 \\
\end{tabular} & $\begin{array}{l}0 \\
2 \\
2 \\
0\end{array}$ & $\begin{array}{l}3 \\
\text { กี } \\
0\end{array}$ & 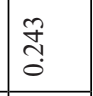 \\
\hline 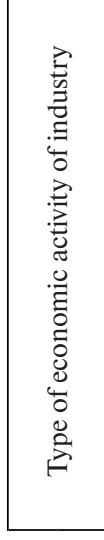 & 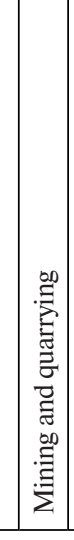 & 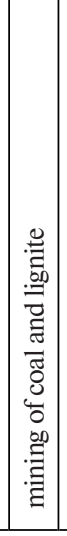 & 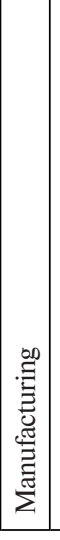 & 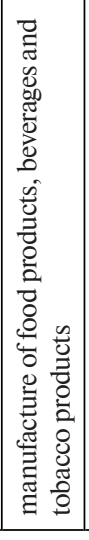 & 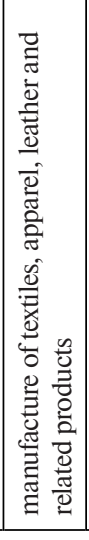 & 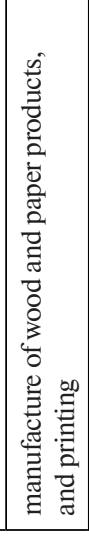 & 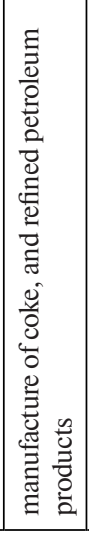 & 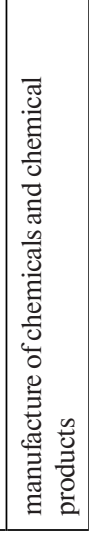 & 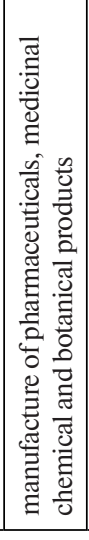 & 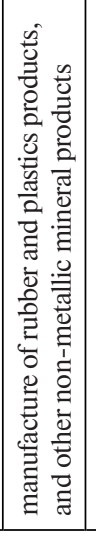 & 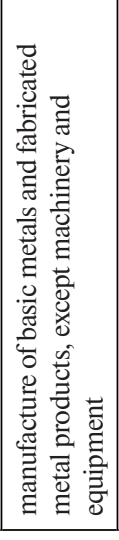 & 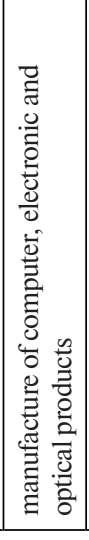 & 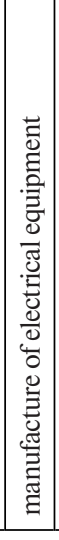 & 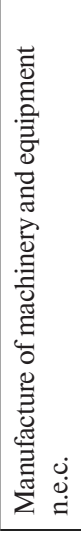 & 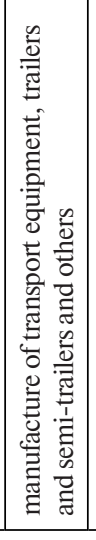 & 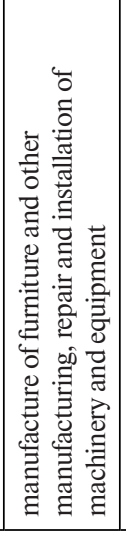 & 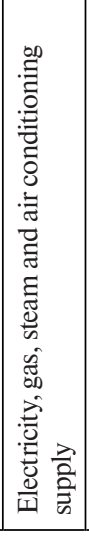 & 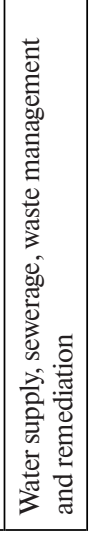 \\
\hline
\end{tabular}


When it comes to the dynamics of the index, it differs in types of economic activity. For instance, in the field of water supply, sewerage, waste management and remediation the level of social responsibility implementation to ensure an adequate level of remuneration decreased in 2018 compared to 2016. A similar trend was recorded for manufacture of computer, electronic and optical products, as well as manufacture of chemicals and chemical products. Furthermore, it should be noted that the most recent worsening of the state of pay was the most critical one: from 0.581 to 0.23 .

However, there are industries for which the calculated index had an opposite trend - it was growing. These include the manufacture of transport equipment, trailers and semi-trailers and others, manufacture of coke, and refined petroleum products, and mining of coal and lignite.

Conclusions. The study resulted in elaborating methodological foundations for the assessment of social responsibility in the field of remuneration. Their core was the calculation of the aggregate index based on the use of stimulators and destimulators. The application of the developed methodological principles will allow the following:

- assessing the effectiveness of remuneration regulation in various types of economic activity, the level of material wellbeing of employees;

- identifying "bottlenecks" and areas of priority changes in the field of motivation and stimulation of employees;

- substantiating socially responsible programmes and practices for employees aimed at ensuring decent remuneration and forming a social package;

- identifying priority areas and developing management decisions to improve remuneration;

- monitoring the implementation of planned regulatory measures in the field of remuneration, while using the system of management audit and the requirements of international social responsibility standards.

Hence, one can consider the results of social responsibility assessment in the field of remuneration as an important tool for substantiating the priority directions of remuneration regulation. This surely determines the relevance of further research, including the search for mechanisms to implement the proposed approach to collective bargaining at different hierarchical levels in order to defend the interests of employees and monitor the implementation of the declared agreements between the social partners.

\section{References.}

1. Levchenko, O. V., \& Moroz, T. V. (2017). Research of indicators of internal corporate social responsibility. Economy and society, 11, 263-269.

2. Libanova, E. M., Makarova, O.V., \& Khmelevskaya, O. M. (2017). Human development in Ukraine: Institutional basis for social responsibility: monograph. Kyiv: Institute of Demography and Social Research named after M. V. Ptyhu NAS of Ukraine. 3. Antonyuk, V. P. (2016). Social policy in the sphere of remuneration: problems and ways to ensure its decent level (on the example of industry). Management of Economics: theory and practice, 3-24.

4. Amosha, O. I., \& Shamileva, L. L. (2016). Development of labor potential of industry on the principles of social responsibility: conceptual and scientific and methodological support. Journal of Economic Sciences of Ukraine, 2, 3-8.

5. Bocharova, N.A., \& Shchepilina, A. K. (2018). The integral assessment of the corporate social responsibility level of enterprise. Economy of the Transport Complex, 31, 45-62.

6. Hrishnova, O.A., Mishchuk, H.Yu., \& Oliynyk, O.O. (2014). Social responsibility in labor relations: theory, practice, risk management: monograph. Rivne: National University of Water and Environmental Engineering.

7. Delini, M. M. (2017). Indicators of assessment of social and economic responsibility of entrepreneurship in Ukraine. Problems of economics, 4, 263-270.
8. Nagaevskaya, D. Yu. (2018). Methodical approach to ensuring social responsibility of business in the food market. Economics and society, 14, 725-734.

9. Pankova, O., \& Kasperovych, O. (2018). Main directions and ways of modernization of the system of social and labor relations in industry on the basis of social responsibility and social dialogue. Ukraine: aspects of labor, 3, 36-43.

10. Zinchenko, A., \& Saprykina, M. (2018). CSR Development in Ukraine: 2010-2018. Retrieved from http://csr-ua.info/ csr-ukraine/wp-content/uploads/2018/10/CSR_2017_reserch-1.pdf.

11. Smachylo, V.V., \& Baliaba, V.O. (2015). Assessment of social responsibility by construction enterprises. Economics: the realities of time, $6(22), 162-169$.

12. Social Accountability Certification (SA 8000) (2007). Retrieved from https://zakon.rada.gov.ua/laws/show/n0015697$\underline{07}$.

13. G4 Sustainability Reporting Guidelines (2018). Retrieved from https://www2.globalreporting.org/standards/g4/Pages/ default.aspx.

14. Mishchuk, G.Y., \& Samolyuk, N. M. (2018). Measuring social justice in the context of evaluating the effectiveness of distribution relations in society. Demography and the social economics, 1, 58-72. https://doi.org/10.15407/dse2018.01.

15. Labor of Ukraine 2018 (2019). Retrieved from http://www. ukrstat.gov.ua/.

16. Labor of Ukraine 2017 (2018). Retrieved from http://www. ukrstat.gov.ua/.

17. Labor of Ukraine 2016 (2017). Retrieved from http://www. ukrstat.gov.ua/.

\section{Оцінювання соціальної відповідальності у сфері оплати праці (на прикладі промисловості)}

\section{О.О. Олійник}

Національний університет водного господарства та природокористування, м. Рівне, Україна, e-mail: oliynuk olena@ukr.net

Мета. Розробити методичні засади оцінювання соціальної відповідальності у сфері оплати праці та іiї інформаційного забезпечення за видами економічної діяльності у промисловості.

Методика. Теоретичним і методологічним підгрунтям дослідження стали фундаментальні положення сучасної економічної теорії, праці вітчизняних і закордонних науковців із проблематики соціально-трудової сфери, соціальної відповідальності, гідної праці. У процесі дослідження були використані такі методи: узагальнення, систематизації, аналізу й синтезу - при аналізі теоретико-методологічних розробок щодо оцінювання соціальної відповідальності у трудових відносинах; статистичний аналіз - для діагностики інформаційного забезпечення реалізації соціальної відповідальності; агрегування - для оцінки соціальної відповідальності у сфері оплати праці; порівняльний аналіз - для діагностики рівня соціальної відповідальності у сфері оплати праці за видами економічної діяльності у промисловості; експертних оцінок - при обгрунтуванні коефіцієнтів вагомості часткових індексів.

Результати. На основі узагальнення й систематизації підходів науковців до визначення змісту соціальної відповідальності у трудових відносинах, аналізу наявних методичних засад при оцінці соціальної відповідальності та критеріїв міжнародних стандартів у цій сфері обгрунтовані показники для оцінювання соціальної відповідальності у сфері оплати праці з їх розподілом на стимулятори та дестимулятори. Розроблено агрегатний індекс для 
визначення рівня соціальної відповідальності у сфері оплати праці, апробовано його розрахунок за видами економічної діяльності у промисловості України.

Наукова новизна. Удосконалені методичні засади оцінювання соціальної відповідальності у сфері оплати праці, в основу яких покладено розрахунок агрегатного індексу на базі використання показників стимуляторів i дестимулятори. На відміну від наявної практики, у методичних основах використані показники, що характеризують рівень дотримання гарантованих нормативно-правових актів різних рівнів, і додаткових зобов'язань в аспекті реалізації концепції соціальної відповідальності.

Практична значимість. Розроблені методичні засади дозволяють із достатньою об'єктивністю оцінювати ефективність регулювання оплати праці в різних видах економічної діяльності, рівень матеріального благополуччя найманих працівників. Використання індексу соціальної відповідальності у сфері оплати праці дозволяє, на основі отриманих часткових та агрегатного показників визначати «вузькі» місця в соціальній політиці та визначати пріоритетні напрями розвитку соціально-трудової сфери. А також слугуватиме основою для покращення взаємодії соціальних партнерів і обгрунтування їх вимог і пропозицій при укладанні колективних договорів та угод різного рівня.

Ключові слова: соціальна відповідальність, оплата праці, трудові відносини, заробітна плата, заборгованість, матеріальна допомога

\section{Оценивание социальной ответственности в сфере оплаты труда (на примере промышленности)}

\section{Е.А. Олейник}

Национальный университет водного хозяйства и природопользования, г. Ровно, Украина, e-mail: oliynuk_olena@ $\underline{\text { ukr.net }}$

Цель. Разработать методические основы оценки социальной ответственности в сфере оплаты труда и ее информационного обеспечения по видам экономической деятельности в промышленности.

Методика. Теоретическим и методологическим основанием исследования стали фундаментальные положения современной экономической теории, труды отечественных и зарубежных ученых по проблемам социально-трудовой сферы, социальной ответственности, достойного труда. В процессе исследования были использованы следующие методы: обобщения, систематизации, анализа и синтеза - при анализе теоретико-методологи- ческих разработок по оценке социальной ответственности в трудовых отношениях; статистический анализ для диагностики информационного обеспечения реализации социальной ответственности; агрегирования - для оценки социальной ответственности в сфере оплаты труда; сравнительный анализ - для диагностики уровня социальной ответственности в сфере оплаты труда по видам экономической деятельности в промышленности; экспертных оценок - при обосновании коэффициентов весомости частных индексов.

Результаты. На основе обобщения и систематизации подходов ученых к определению содержания социальной ответственности в трудовых отношениях, анализа имеющихся методических основ при оценке социальной ответственности и критериев международных стандартов в этой сфере обоснованы показатели для оценки социальной ответственности в сфере оплаты труда с их делением на стимуляторы и дестимуляторы. Разработан агрегатный индекс для определения уровня социальной ответственности в сфере оплаты труда, апробирован его расчет по видам экономической деятельности в промышленности Украины.

Научная новизна. Усовершенствованы методические основы оценки социальной ответственности в сфере оплаты труда, в основе которых положен расчет агрегатного индекса на базе использования показателей стимуляторов и дестимуляторов. В отличие от существующей практики, в методических основах использованы показатели, характеризующие уровень соблюдения гарантированных нормативно-правовых актов различных уровней, и дополнительных обязательств в аспекте реализации концепции социальной ответственности.

Практическая значимость. Разработанные методические основы позволяют с достаточной объективностью оценивать эффективность регулирования оплаты труда в различных видах экономической деятельности, уровень материального благополучия наемных работников. Использование индекса социальной ответственности в сфеpe оплаты труда позволяет, на основе полученных частичных и агрегатного показателей, определять «узкие» места в социальной политике и определять приоритетные направления развития социально-трудовой сферы. А также послужит основой для улучшения взаимодействия социальных партнеров и обоснования их требований и предложений при заключении коллективных договоров и соглашений различного уровня.

Ключевые слова: социальная ответственность, оплата труда, трудовые отношения, заработная плата, задолженность, материальная помощь

Recommended for publication by H. Yu. Mishchuk, Doctor of Economic Sciences. The manuscript was submitted 17.10.19. 